\title{
Current clinical criteria for Lynch syndrome are not sensitive enough to identify MSH6 mutation carriers
}

\author{
Wenche Sjursen, ${ }^{1,2}$ Bjørn Ivar Haukanes, ${ }^{3}$ Eli Marie Grindedal, ${ }^{4}$ Harald Aarset, ${ }^{1}$ \\ Astrid Stormorken, ${ }^{5}$ Lars F Engebretsen, ${ }^{3}$ Christoffer Jonsrud, ${ }^{6}$ Inga Bjørnevoll, ${ }^{1}$ \\ Per Arne Andresen, ${ }^{7}$ Sarah Ariansen, ${ }^{7}$ Liss Anne S Lavik, ${ }^{1}$ Bodil Gilde, \\ Inger Marie Bowitz-Lothe, ${ }^{5}$ Lovise Mæhle, ${ }^{4}$ Pål Møller ${ }^{4}$
}

\begin{abstract}
'Department of Pathology and Medical genetics, St Olavs University Hospital, Trondheim, Norway

${ }^{2}$ Department of Laboratory Medicine Children's and Women's Health, Norwegian University of Science and Technology, Trondheim, Norway ${ }^{3}$ Center for Medical Genetics and Molecular Medicine, Haukeland University Hospital, Bergen, Norway

${ }^{4}$ Department of medical genetics, Oslo University Hospital, Radiumhospitalet, Oslo, Norway

${ }^{5}$ Department of Medical Genetics, Oslo University Hospital, Ullevål, Norway ${ }^{6}$ University Hospital of North Norway, Division of Child and Adolescent Health, Department of Medical Genetics, Tromsø. Norway

${ }^{7}$ Department of Pathology, Oslo University Hospital, Rikshospitalet, Oslo, Norway
\end{abstract}

\section{Correspondence to}

Dr Wenche Sjursen, Department of Pathology and Medical Genetics, Erling Skjalgssons gt 1, St Olavs University Hospital, 7006 Trondheim, Norway; wenche.sjursen@stolav.no

Received 29 January 2010 Accepted 27 March 2010 Published Online First 28 June 2010

\section{ABSTRACT}

Background Reported prevalence, penetrance and expression of deleterious mutations in the mismatch repair (MMR) genes, MLH1, MSH2, MSH6 and PMS2, may reflect differences in the clinical criteria used to select families for DNA testing. The authors have previously reported that clinical criteria are not sensitive enough to identify MMR mutation carriers among incident colorectal cancer cases.

Objective To describe the sensitivity of the criteria when applied to families with a demonstrated MMR mutation.

Methods Families with an aggregation of colorectal cancers were examined for deleterious MMR mutations according to the Mallorca guidelines. All families with a detected MMR mutation as of November 2009 were reclassified according to the Amsterdam and Bethesda criteria.

Results Sixty-nine different DNA variants were identified in a total of 129 families. The original Amsterdam clinical criteria were met by $38 \%, 12 \%, 78 \%$ and $25 \%$ of families with mutations in MSH2, MSH6, MLH1 and PMS2, respectively. Corresponding numbers for the revised Amsterdam criteria were 62\%, 48\%, 87\% and 38\%. Similarly, each of the four clinical Bethesda criteria had low sensitivity for identifying MSH6 or PMS2 mutations. Conclusion Amsterdam criteria and each of the Bethesda criteria were inadequate for identifying MSH6 mutation-carrying kindreds. MSH6 mutations may be more common than currently assumed, and the penetrance/expression of MSH6 mutations, as derived from families meeting current clinical criteria, may be misleading. To increase detection rate of MMR mutation carriers, all cancers in the Lynch syndrome tumour spectrum should be subjected to immunohistochemical analysis and/or analysis for microsatellite instability.

\section{INTRODUCTION}

The concept of hereditary non-polyposis colorectal cancer (HNPCC) was developed to denote families with inherited colorectal cancer (CRC). The Amsterdam (AMSI) criteria identified families with CRC. ${ }^{1}$ As extracolonic cancers, especially endometrial cancer, were shown to be part of the inherited syndrome, ${ }^{2} 3$ the revised Amsterdam criteria (AMSII) were introduced. ${ }^{4}$ The Bethesda guidelines included the tumour marker microsatellite instability (MSI), ${ }^{5}$ and the revised Bethesda criteria (BII) specified all cancers known at the time to be asso- ciated with the syndrome. ${ }^{6}$ Prostate cancer has recently been shown to possibly be part of the syndrome. ${ }^{7}$ Germline mutations in the mismatch repair (MMR) genes, MLH1, MSH2, MSH6 and PMS2, have been identified to cause HNPCC (reviewed by Lynch and Lynch ${ }^{8}$ ). However, it has become clear that not all families fulfilling the clinical criteria have an identifiable deleterious mutation (hereafter called 'mutation') in one of these genes. In addition, because MMR mutations confer an increased risk of several types of cancer in addition to CRC, it has been suggested that the term Lynch syndrome should replace HNPCC in families where a mutation has been detected. ${ }^{9}$ This definition of Lynch syndrome will be used in the present report. Families fulfilling the AMSII criteria without a demonstrable MMR mutation may be denoted HNPCC. Families with an aggregation of CRC and not corresponding to Lynch syndrome or HNPCC may be referred to as familial CRC. ${ }^{9}$

Tumours caused by mutations in MLH1, MSH2, MSH6 and PMS2 show a high degree of MSI. It has been shown by immunohistochemical analysis (IHC) that the gene product from the mutated gene is absent in tumour tissue (reviewed by Vasen et a ${ }^{10}$ ). IHC and MSI analysis have high sensitivity in detecting carriers of MMR mutations. ${ }^{11}{ }^{12}$ It is now customary to examine tumours in families that fulfil clinical criteria by IHC/MSI analysis, and select those families with abnormal results for analysis of constitutional DNA. ${ }^{10}$ As a consequence, families not meeting the clinical criteria will not be subjected to mutation analyses.

Varying prevalence of mutations in the MMR genes has been reported. Some variations are obviously caused by geographically local and frequent founder mutations. ${ }^{13-16}$ It is, however, reasonable to assume that the criteria used to select families for testing may also have influenced the results.

Over the last two decades, Norwegian cancer genetic clinics have recruited families with an aggregation of cancers of any type. Thousands of cancer kindreds have been examined for hereditary cancer syndromes. Reports from this are listed on http:// www.inherited-cancer.com. Upon referral, the families were classified using preset wide-ranging criteria, and IHC/MSI analyses were performed not only on the families that met the clinical criteria for HNPCC and familial CRC. We here report the sensitivities of the AMSI, AMSII and BII criteria when applied to families that were shown by genetic testing to have an MMR mutation. As Norwegian legislation 
dictates that genetic testing is restricted to clinical departments, and as all genetic departments collaborated in this report, we here present a complete report of all clinical genetic activity in a defined population up to November 2009.

\section{PATIENTS AND METHODS Patients, registries and ethics}

The initial material included all families investigated for inherited CRC in Norway until November 2009. Wide-ranging selection criteria were used to identify the families. Besides including all kindreds meeting the AMSII or BII criteria, we explored all families with four CRC cases irrespective of age and including skipped generations or with an aggregation of any cancer associated with Lynch syndrome. All activities were conducted as part of the healthcare system, all information was included in the patient files, all genetic testing was conducted according to national legislation, including genetic counselling before and after genetic testing, and all genetic testing was performed with written informed consent from the participants. All relevant diagnoses in the families were validated in the medical files or cancer registry after consent from relatives or descendants if the subject was dead. No research registry that included names was produced; only summarised data were taken from medical files for compilation of the present report. All information described has been disclosed to the patients/families, and family members were offered appropriate healthcare according to the Mallorca guidelines. ${ }^{9}$

\section{MSI/IHC examinations}

Upon referral and inclusion according to the wide-ranging criteria, families were subjected to examination for Lynch syndrome as described in the Mallorca guidelines, with IHC/ MSI analysis of at least two affected family members if available, ${ }^{9}$ continuing to full mutation analysis of the relevant gene(s) of the patient (or obligate carrier in the family or offspring if dead) if an abnormal IHC result was obtained. A family was scored as having an abnormal IHC result if one or more tumour(s) showed lack of staining for the gene product of one or more of the MMR genes. Full mutation analysis of all MMR genes was performed if IHC was normal but the tumours were MSI (MSI-high). In some selected families, mutation analyses were also performed in the absence of MSI/abnormal IHC.

\section{Molecular methods}

MMR mutation analyses included heteroduplex identification followed by DNA sequencing of the actual MMR gene(s). Analysis of gross deletions and duplications was performed by multiplex ligation-dependent probe amplification assay (MLPA; SALSA P003 MLH1/MSH2, P008 MSH6/PMS2 and P072-MSH6; MRC-Holland, http://www.mrc-holland.com). Results for PMS2 exon 13-15 probes were disregarded because many related sequences are present in the genome and the probes provided very variable results. Sequencing analyses were performed on an ABI Genetic Analyzer model 3100 or 3130 (Applied Biosystems, Carlsbad, CA, USA), and DNA sequences were computed using SeqScape v2.5 software (Applied Biosystems). Primer and sequence details are available on request. In some cases of putative splice effects, cDNA analyses of $M L H 1$, MSH2, MSH6 and PMS2 were performed. The molecular analyses were performed according to standard procedures and manufacturers' instructions. Methods used varied over time and between the different laboratories involved. It was beyond our means to reanalyse the whole series so that one method was applied to all cases for the present report.

\section{Classification of DNA variants}

Reference sequences used were as follows (GeneBank http:// www.ncbi.nlm.nih.gov/genbank): $M L H 1$, NT 022517 (transcript: NM_000249.2); MSH2, NT_022184 (transcript: NM_000251.1); $M S \bar{H} 6$, NT_0221844 (transcript: NM_000179.1); PMS2, AC005995.3 (transcript: BC093921.1). Detected DNA variants were checked against published mutations in the following websites: http://www.insight-group.org (LOVD: Leiden Open Variation Database), https://portal.biobase-international.com/ hgmd/pro/start.php (Human Gene Mutation Database), Pub Med and http://www.med.mun.ca/MMRvariants. ${ }^{17}$ Mutations causing direct stop/nonsense, frameshifts, splice defects and large insertions/deletions were considered deleterious. Missense mutations or small in-frame deletions were subjected to segregation analysis when possible. ${ }^{18}$ If a review of the international databases or segregation analyses strongly suggested the variant to be deleterious, the mutations were scored accordingly. The reasons for scoring of each mutation are given in table 1. All other DNA variants were considered part of normal variation or the information available on the variant and family was insufficient for conclusive scoring. These variants were excluded from the report.

\section{Clinical classification}

All families in which an MMR mutation (ie, with confirmed Lynch syndrome) had been detected were reclassified according to clinical criteria with the information obtained as of November 2009. Thus the classification does not reflect the starting point with the information at hand at referral, but rather the information obtained after having expanded all Lynch syndrome families and verified all relevant diagnoses for all family members in the medical files or cancer registry. The families were classified according to the AMSI, AMSII or BII criteria. Furthermore, the scoring for BII criteria was specified according to the subgroups given in Umar et al ${ }^{6}$ : BII_1 (CRC $<50$ years), BII_2 (synchronic/metachronic cancers), BII_4 (two affected relatives, one $<50$ years) and/or BII_5 (relatives with HNPCC-associated tumours). For precise definitions of groups as applied, see Umar et al. ${ }^{6}$ BII_3 includes MSI, which was a selection criterion for DNA analysis, and was not used to categorise mutation-carrying kindreds revealed this way. Also, MSI is a laboratory finding and not a clinical criterion. The combined BII criteria were possibly too close to our inclusion criteria for the total cohort studied, and scoring for the combined BII criteria could not be considered a result.

\section{RESULTS}

Sixty-nine different mutations were identified in a total of 129 families. Of these, 31 (45\%) were detected in MSH2, $19(27 \%)$ in MSH6, 15 (22\%) in MLH1, and four (6\%) in PMS2. Sixty-five $(50 \%)$ of the families had a mutation in MSH2, $33(26 \%)$ in MSH6, 23 (18\%) in MLH1, and eight (6\%) in PMS2. The total numbers of mutation carriers were 514, of whom 248 (48\%), 146 (28\%), 98 (19\%) and 22 (4\%) had a mutation in MSH2, MSH6, MLH1 and PMS2, respectively.

Frameshift mutations $(n=24)$ and splice defects $(n=18)$ were the most common aberrations. Other types of mutations were nonsense mutations creating new stop codons $(n=13)$, large genomic (exon) deletions $(n=8)$, in-frame deletions of three nucleotides $(n=3)$ and missense mutations $(n=3)$. There were no indications that the nature of mutations differed between the different genes, and no further statistical analyses based on the nature of the mutation were undertaken. 
Table 1 Deleterious mismatch repair (MMR) mutations in the Norwegian population ${ }^{22} 31$

\begin{tabular}{|c|c|c|c|c|c|c|c|c|}
\hline $\begin{array}{l}\text { Type of } \\
\text { mutation/gene }\end{array}$ & Mutation & $\begin{array}{l}\text { Effect of mutation } \\
\text { (verified or predicted) }\end{array}$ & Family No & $\begin{array}{l}\text { No of } \\
\text { mut+ }\end{array}$ & $\begin{array}{l}\text { IHC (missing } \\
\text { protein) }\end{array}$ & $\begin{array}{l}\text { Inclusion criteria: } \\
\text { Amsterd. } \neq \ddagger\end{array}$ & $\begin{array}{l}\text { Inclusion } \\
\text { criteria: BII } \S \S\end{array}$ & Ref. \\
\hline \multicolumn{9}{|l|}{ Frameshift } \\
\hline \multirow[t]{2}{*}{ MLH1e1 } & c.39_40dupGA & p.Thr14ArgfsX3 & H1855 (D4354) & 6 & MLH1/PMS2 & $|\&| \mid$ & $1,2,4 \& 5$ & LOVD \\
\hline & & & $\mathrm{D} 20$ & 1 & MLH1/PMS2 & $|\&| \mid$ & $1,2,4 \& 5$ & \\
\hline MLH1e5 & c.413delC & p.Pro138LeufsX21 & U82517 & 1 & MLH1/PMS2 & $|\&| \mid$ & $1,2,4 \& 5$ & ๑ा \\
\hline MLH1e10 & c.866_867delAC & p.His289ProfsX16 & H836 & 2 & MLH1/PMS2 & $|\&| \mid$ & $1,2,4 \& 5$ & LOVD \\
\hline MLH1e16 & c.1771dupG & p.Asp591GlyfsX1 & U97760 & 3 & MLH1\&PMS2 & $|\&| \mid$ & $1,2,4 \& 5$ & ๑ศ \\
\hline MSH2e2 & c.229_230delAG & p.Ser77CysfsX3 & H3323 & 1 & MSH2/MSH6 & 0 & 1 & LOVD \\
\hline MSH2e4 & c.675_678delAGAA & p.Thr225ThrfsX19 & D2679 & 1 & MSH2/MSH6 & $\|$ & $1,4 \& 5$ & ศा \\
\hline \multirow[t]{2}{*}{ MSH2e 6} & c.969_970delTC & p. Gln324ValfsX8 & U85816 & 2 & MSH2/MSH6 & | \& || & $1,2,4$ \& 5 & ब๑ \\
\hline & & & D2033 & 1 & MSH2/MSH6 & $\mid \& \|$ & $1,2,4 \& 5$ & \\
\hline MSH2e7 & c.1204delC & p.Gln402LysfsX10 & H677 & 1 & MSH2/MSH6 & $\|$ & $1,4 \& 5$ & LOVD \\
\hline MSH6e4 & c.900dupG & p.Lys301GlufsX11 & U88612 & 2 & MSH2/MSH6 & ॥ & $2,4 \& 5$ & ๑๑ \\
\hline MSH6e4 & c.1405delT & p.Tyr469llefsX11 & S254 & 9 & normal $†$ & ॥ & 5 & ब \\
\hline MSH6e4 & c.1943delG & p.Ser648MetfsX5 & $\mathrm{H} 2327$ & 3 & MSH2/MSH6 & 0 & $1,2 \& 4$ & ฯ \\
\hline MSH6e4 & c.2604delG & p.Met868llefsX5 & D1731 & 3 & MSH6 & ॥ & $2 \& 5$ & ๑๑ \\
\hline MSH6e5 & c.3195_3199delCTATA & p.Asn1065LysfsX4 & $\mathrm{D} 2115$ & 5 & MSH6 & $\|$ & $1,4 \& 5$ & LOVD \\
\hline \multirow[t]{4}{*}{ MSH6e5 } & c.3261-̄upc & p.Phe1088LeufsX5 & H1408 & 1 & MSH6 & $|\&| \mid$ & $1,4 \& 5$ & LOVD \\
\hline & & & S631 & 7 & MSH6 & 0 & $1 \& 2$ & \\
\hline & & & S1108 & 4 & MSH6 & $\|$ & $1,2 \& 4$ & \\
\hline & & & T02 & 2 & MSH2/MSH6 & $|\&| \mid$ & $1,2,4 \& 5$ & \\
\hline MSH6e5 & 3261 delC & p.Phe1088ProfsX2 & D867 & 8 & MSH6 & 0 & $2 \& 5$ & LOVD \\
\hline MSH6e6 & c.3514dupA & p.Arg1172LysfsX4 & U94618 & 1 & MSH6 & $\|$ & 2 & LOVD \\
\hline MSH6e9 & c.3804dupA & p.Cys1269MetfsX5 & U61010 & 7 & MSH2/MSH6 & 0 & $2 \& 5$ & LOVD \\
\hline PMS2e14 & c.2382dupT & p.Gly795TrpfsX29 & T92 & 3 & PMS2 & 0 & $2 \& 5$ & ฯब \\
\hline \multicolumn{9}{|l|}{ Splice defect } \\
\hline MLH1int9 & c. $790+1 \mathrm{G} \rightarrow \mathrm{A}$ & Skipping of exon 9-10 & $\mathrm{H} 285$ & 2 & ND & 0 & $1,4 \& 5$ & LOVD \\
\hline MLH1int9 & c. $791-2 A \rightarrow G$ & Splice defect & T04 (S639 \& H1547)) & 8 & MLH1/PMS2 & $|\&| \mid$ & $1,2,4 \& 5$ & LOVD \\
\hline MLH1e10 & c.793C $\rightarrow \mathrm{T}$ & p.Arg265Cys $\ddagger$ & $\mathrm{D} 490$ & 10 & MLH1/PMS2 & $|\&| \mid$ & $1,2,4 \& 5$ & LOVD \\
\hline MLH1e15 & c. $1731 \mathrm{G} \rightarrow \mathrm{C}$ & Skipping of exon $15 \S$ & U1001245 & 3 & MLH1/PMS2 & 1 & $1,2,4 \& 5$ & $\begin{array}{l}\text { LOVD } \\
(\text { c. } 1731 \mathrm{G} \rightarrow \mathrm{A})\end{array}$ \\
\hline MLH1int15 & c. $1731+1 \mathrm{G} \rightarrow \mathrm{C}$ & Splice defect & D1532 & 1 & MLH1/PMS2 & ॥ & $1,2,4$ \& 5 & LOVD \\
\hline MSH2e5 & $\mathrm{c} .815 \mathrm{C} \rightarrow \mathrm{T}$ & r. $(=)+(=; 793$ 992del $) \uparrow$ & S403 & 5 & MSH2/MSH6 & 0 & $2,4 \& 5$ & LOVD \\
\hline \multirow[t]{12}{*}{ MSH2int5 } & c. $942+3 \mathrm{~A} \rightarrow \mathrm{T}$ & r. $(=)+\left(793 \_942 \mathrm{del}\right) \uparrow$ & $\mathrm{H} 07$ & 5 & ND & $\|$ & $1,2,4 \& 5$ & LOVD \\
\hline & & & H892* & 3 & MSH2/MSH6 & $\|$ & $1,2,4 \& 5$ & \\
\hline & & & H1503 (S551) & 4 & MSH2/MSH6 & 0 & $1,2,4 \& 5$ & \\
\hline & & & H1598 (S583) & 3 & MSH2/MSH6 & $॥$ & $1,2,4 \& 5$ & \\
\hline & & & $\mathrm{H} 2215$ & 4 & MSH2/MSH6 & $|\&| \mid$ & $1,2,4 \& 5$ & \\
\hline & & & $\mathrm{H} 2280$ & 1 & MSH2/MSH6 & 0 & $1,2,4 \& 5$ & \\
\hline & & & U101185 & 1 & MSH2/MSH6 & $\|$ & $1,4 \& 5$ & \\
\hline & & & T059 & 3 & MSH2/MSH6 & 0 & $1,4 \& 5$ & \\
\hline & & & T073 & 9 & MSH2/MSH6 & 0 & $1,2,4 \& 5$ & \\
\hline & & & D637 & 3 & MSH2/MSH6 & 0 & $4 \& 5$ & \\
\hline & & & D1211 & 11 & MSH2/MSH6 & $|\&| \mid$ & $1,2,4 \& 5$ & \\
\hline & & & D4522 & 2 & MSH2/MSH6 & 0 & $1,2 \& 5$ & \\
\hline \multirow[t]{2}{*}{ MSH2int6 } & c. $1076+1 \mathrm{G} \rightarrow \mathrm{A}$ & Skipping of exon 6 & $\mathrm{H} 1903$ & 5 & MSH2/MSH6 & 0 & $1,4 \& 5$ & LOVD \\
\hline & & & D1773 & 5 & MSH2/MSH6 & 0 & $2 \& 5$ & \\
\hline MSH2int7 & c. $1277-2 \mathrm{~A} \rightarrow \mathrm{G}$ & r. $\left(=, 1277 \_1386\right.$ del $) \Phi$ & S577 & 9 & MSH2/MSH6 & $|\&| \mid$ & $1,2 \& 4$ & LOVD \\
\hline
\end{tabular}


Table 1 Continued

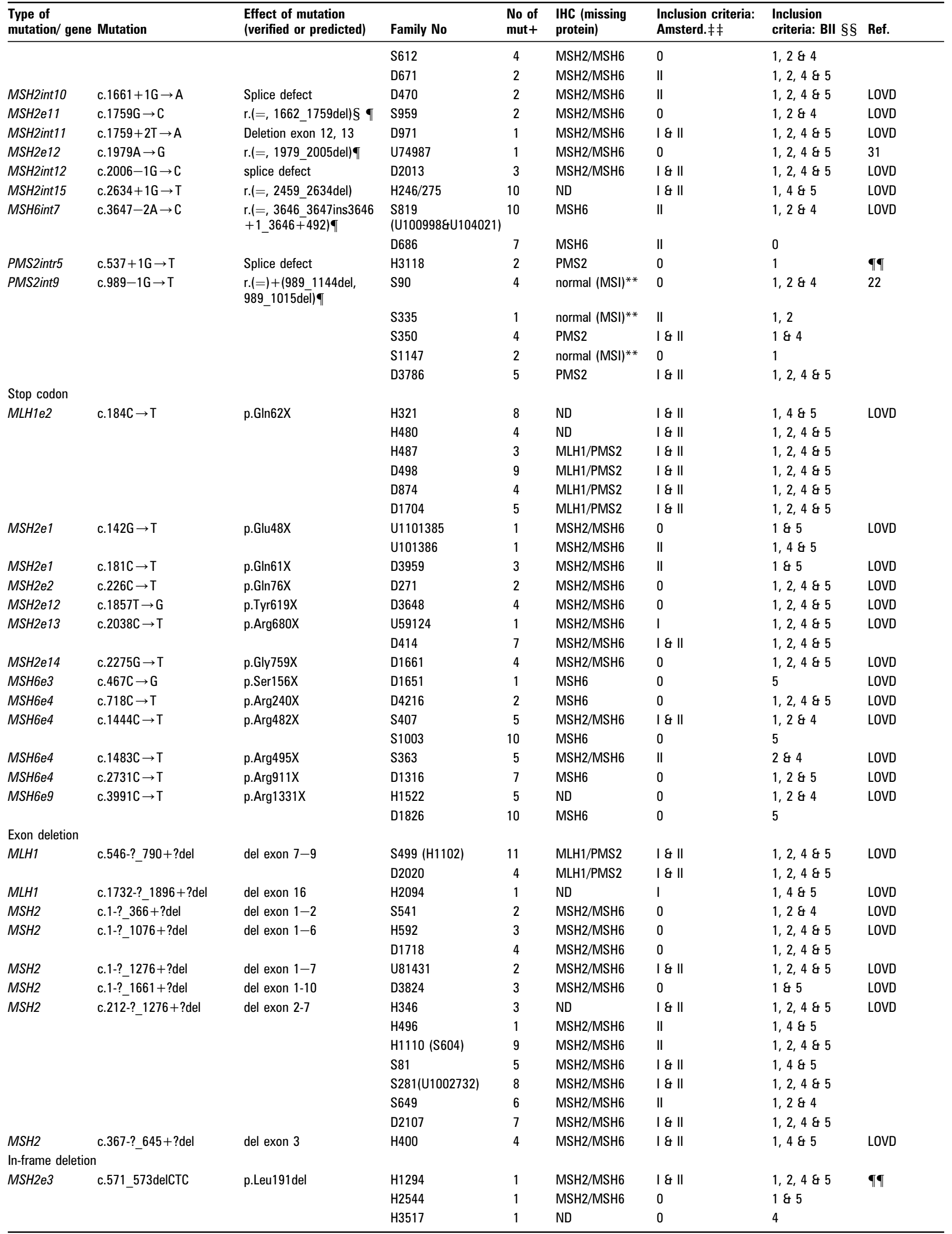


Table 1 Continued

\begin{tabular}{|c|c|c|c|c|c|c|c|c|}
\hline $\begin{array}{l}\text { Type of } \\
\text { mutation/gene }\end{array}$ & Mutation & $\begin{array}{l}\text { Effect of mutation } \\
\text { (verified or predicted) }\end{array}$ & Family No & $\begin{array}{l}\text { No of } \\
\text { mut+ }\end{array}$ & $\begin{array}{l}\text { IHC (missing } \\
\text { protein) }\end{array}$ & $\begin{array}{l}\text { Inclusion criteria: } \\
\text { Amsterd. } \neq \ddagger\end{array}$ & $\begin{array}{l}\text { Inclusion } \\
\text { criteria: BII } \S \S\end{array}$ & Ref. \\
\hline & & & U90087 & 1 & MSH2/MSH6 & ॥ & $1,2,4 \& 5$ & \\
\hline & & & U1000173 & 2 & MSH2/MSH6 & II & $1,4 \& 5$ & \\
\hline & & & T382 & 3 & MSH2/MSH6 & 0 & $1,4 \& 5$ & \\
\hline \multirow[t]{6}{*}{ MSH2e12 } & c.1786_1788delAAT & p.Asn596del & D554 & 19 & MSH2/MSH6 & | \& || & $1,2,4 \& 5$ & LOVD \\
\hline & & & D853 & 5 & MSH2/MSH6 & | \& || & $1,2,4 \& 5$ & \\
\hline & & & D3618 & 5 & MSH2/MSH6 & | \& || & $1,2,4 \& 5$ & \\
\hline & & & D3667 & 3 & MSH2/MSH6 & | \& || & $1,2,4 \& 5$ & \\
\hline & & & D3707 & 7 & MSH2/MSH6 & | \& || & $1,2,4 \& 5$ & \\
\hline & & & D4202 & 2 & MSH2/MSH6 & II & $1,2,4 \& 5$ & \\
\hline \multirow[t]{4}{*}{ MSH6e4 } & c.2302_2304delCCT & p.Pro768del & H801 & 2 & MSH2/MSH6 & 0 & $1,2,4 \& 5$ & LOVD \\
\hline & & $4 / 14$ & $\mathrm{H} 2160$ & 5 & ND & 0 & $2,4 \& 5$ & \\
\hline & & & S149 & 5 & MSH2/MSH6 & 0 & $1 \& 5$ & \\
\hline & & & S647 & 3 & MSH2/MSH6 & II & 2 & \\
\hline \multicolumn{9}{|l|}{ Missense } \\
\hline MLH1e3 & c. $245 \mathrm{C} \rightarrow \mathrm{T}$ & p.Thr82lle & S420†† & 6 & normal $(\mathrm{MSI})^{* *}$ & II & $1,4 \& 5$ & LOVD \\
\hline MLH1e16 & c. $1823 \mathrm{C} \rightarrow \mathrm{A}$ & p.Ala608Asp & S581†† & 2 & MLH1/PMS2 & II & $1,2 \& 4$ & LOVD \\
\hline MSH6e4 & c. $2906 \mathrm{~A} \rightarrow \mathrm{G}$ & p.Tyr969Cys & D2955†† & 6 & MSH6 & | \& || & $1,2,4 \& 5$ & LOVD \\
\hline
\end{tabular}

*Two pathogenic mutations in two branches in the same family.

†No indications from IHC or microsatellite instability.

$\ddagger$ Reported to affect splicing and stability.

§Last nucleotide in exon; reported to cause skipping of exon

TShown in present study to give aberrant splicing.

**Normal protein expression, but microsatellite instability.

$\dagger+$ Cosegregation with disease.

$\neq \ddagger$ Amsterdam I and/or Amsterdam II.

$\S \S$ Bethesda II (revised), see text for details.

ฯ $\uparrow$ Not found to be reported in databases.

IHC, immunohistochemical analysis; LOVD, Leiden Open Variation Database (http://www.insight-group.org/mutations/); mut+, mutation carriers; ND, not done.

Details on the prevalence of each mutation are given in table 1. Forty-nine of the 69 mutations were exclusively found in one family. There were no mutations that were frequent enough to have a significant effect on the distributions observed between the different genes. The most recurrent mutation, MSH2 c. $942+3 \mathrm{~A} \rightarrow \mathrm{T}$, was found in 12 apparently unrelated families (49 people) from different geographical locations and has been described in other populations. ${ }^{19-21}$ It has possibly been introduced more than once into our population. The majority of the remaining recurrent mutations could be traced to confined geographical areas and were considered to be branches from a common origin (founder mutations). Families with deleterious PMS2 mutations were limited. One single mutation $(c .989-1 \mathrm{G} \rightarrow \mathrm{T})^{22}$ accounted for the majority of PMS2 mutation-carrying kindreds, all from the same (small) area. Average numbers of demonstrated mutation carriers per family were similar for all mutations; details are shown in table 2 .

Tumour tissue was available for IHC and MSI analysis for most of the families later demonstrated to have an MMR mutation. The IHC results are shown in table 1. All but five families showed abnormal IHC corresponding to the gene mutated. Tumours from three of five kindreds with the founder PMS2 splice variant, c.989-1G $\rightarrow \mathrm{T}$, mentioned above expressed PMS2 normally but showed MSI (MSI-high). Similarly, tumour tissue from one family with a missense mutation in $M L H 1$ $(\mathrm{c} .245 \mathrm{C} \rightarrow \mathrm{T}$ (p.Thr82lle)) showed normal IHC and MSI (MSIhigh). Apparently normal expression of $M L H 1$ indicated by IHC in MSI-high tumours is in agreement with another report. ${ }^{23}$ In the family with the c.1405delT, in MSH6, the tumour showed normal IHC and was microsatellite stable (MSS).

The mutation-positive families that fulfilled the various clinical criteria when reclassified are detailed in table 2 . Thirty-eight per cent of $M S H 2$ families, $12 \%$ of $M S H 6$ families, $78 \%$ of $M L H 1$ families and $25 \%$ of PMS2 families met the AMSI criteria. Corresponding sensitivity for the AMSII criteria for identifying mutations in the different genes were $62 \%, 48 \%, 87 \%$ and $38 \%$. Similarly, each of the clinical Bethesda criteria had low sensitivity for identifying MSH6 and PMS2 mutations.

\section{DISCUSSION}

In this study in which all national activity was compiled, we found that most families with $M L H 1$ mutations were identified by any of the clinical criteria used. The criteria that included extracolonic cancers (AMSII) identified two out of three $\mathrm{MSH} 2$ mutations, whereas $\mathrm{MSH} 6$ mutations were not identified with reasonable sensitivity by any of the single clinical criteria. As these results were obtained after expanding all mutation-

Table 2 Summary of deleterious variants according to gene, number of mutation carriers and which clinical criteria are fulfilled

\begin{tabular}{|c|c|c|c|c|c|c|c|c|c|c|}
\hline Gene & No of families & No of mut+ & Fraction of mutations (in \%) & No of mut+/family & AMSI & AMSII & BII_1 & BII_2 & BII_4 & BII_5 \\
\hline MSH2 & 65 & 248 & 50 & 3.82 & $25(10.38)$ & $40(10.62)$ & $61(10.94)$ & 46 (10.71) & $58(10.89)$ & 57 (10.88) \\
\hline MSH6 & 33 & 146 & 26 & 4.42 & 4 (10.12) & $16(10.48)$ & $15(10.45)$ & $24(10.72)$ & $16(10.48)$ & $22(10.67)$ \\
\hline MLH1 & 23 & 98 & 18 & 4.26 & $18(10.78)$ & $20(10.87)$ & $23(11.00)$ & $20(10.87)$ & $23(11.00)$ & $23(11.00)$ \\
\hline Total & 129 & 514 & 100 & 3.98 & & & & & & \\
\hline
\end{tabular}

AMSI/II, Amsterdam I/II criteria; BII, Bethesda II criteria; mut+, mutation carriers. 
carrying kindreds, we consider them to be maximum estimates. The sensitivities for detecting mutation-positive families upon referral were lower.

The most sensitive single clinical criterion for identifying MSH6 mutation carriers was the presence of two independent primary cancers (BII_2) (table 2). This information is, however, awaiting detailed validation of diagnoses in the families and may not be easily obtainable when interviewing a family member.

We have recently reported that, when applied to a consecutive series of unselected patients with CRC, the sensitivities of AMSII and BII criteria were as low as $25 \%$ and $50 \%$, respectively. ${ }^{12}$ Moreover, awareness of hereditary cancer among clinicians involved in diagnosis and treatment of CRC is low, and families actually meeting the criteria may not be identified. ${ }^{24}$ These points highlight the challenges associated with using family history for detecting families with MMR mutations. Our combined findings support the suggestion by the Mallorca group to apply IHC and/or MSI analysis to all CRCs to identify MMR mutation carriers. ${ }^{25}$ As MSH6 mutation carriers are likely to develop extracolonic cancers, it may be justified to suggest that all cancer phenotypes associated with Lynch syndrome should be subjected to IHC and/or MSI analysis and subsequent DNA mutation analysis. Until such studies have been performed, we remain cautious when discussing the prevalence of $\mathrm{MSH} 6$ mutations. Correspondingly, the current estimates of penetrance/expression of $\mathrm{MSH} 6$ mutations may be (partly) derived from families fulfilling current clinical criteria. 2627 These estimates may be misleading, as they may reflect the criteria used to select the families from which the estimates were derived.

MLH1 mutations were less common than assumed from previous reports, ${ }^{8}$ and $\mathrm{MSH} 2$ mutations accounted for almost half of all kindreds with a mutation. Despite the fact that the criteria used were insensitive for detecting MSH6 mutations, the number of $M S H 6$ mutation-carrying kindreds were higher than MLH1 mutation-carrying kindreds.

None of the mutations were common enough to affect the distribution significantly, with respect to neither number of mutation-carrying kindreds nor number of mutation-carrying people. Despite the difference in prevalence of mutations in the different genes, the mean number of mutation carriers per family was similar for all the genes.

A Danish study reported a relatively high prevalence of $\mathrm{MSH} 6$ mutations. $^{20}$ If this were due to similarities between these neighbouring populations, we would have expected to detect founder mutation(s) in both populations, but this was not the case. The reason for the similar results may be the study designs. Both studies applied wide criteria for IHC and MSI analysis.

The number of carriers of PMS2 mutations was insufficient for sophisticated statistical analysis. Part of the explanation may be that testing for PMS2 mutations has not been available for as long as testing for mutations in the other genes. Also, most of the few PMS2 mutation carriers were included in several branches of one old family. Some of these branches were not identified by IHC, but the tumours displayed MSI (MSI-high). Thus, by performing only IHC and not MSI analysis to prescreen for mutation testing, a few mutations may have been missed. This indicates that MSI analysis is of importance if IHC shows normal expression of all MMR genes. MMR mutations cannot be excluded if neither analysis has been performed. Technical problems involved in DNA PMS2 mutation analyses are well known. ${ }^{28-30}$ Current procedures (including both technical aspects and clinical criteria) may be insufficient to detect PMS2 mutations, and current estimates of prevalence of PMS2 mutations may be too low.
IHC was used as a selection criterion for mutation analysis and could not be scored as a result. The result of all efforts to examine selected families without abnormal IHC or MSI for mutations was the identification of a single mutation-carrying family (family S254, MSH6 c.1405delT). The study was not designed to assess sensitivity of IHC/MSI, and we will not discuss this further. Our impression from other reports is, however, that IHC and MSI analyses are more sensitive than any clinical criteria for identifying kindreds carrying $M S H 2$ or MSH6 mutations, in particular, ${ }^{11}{ }^{12}$ and the present report is in keeping with that notion.

In conclusion, we observed that $87 \%$ of families with an MLH1 mutation, $62 \%$ with an MSH2 mutation, but less than half of families with an MSH6 or PMS2 mutation were identified by the AMSII criteria. Each of the clinical Bethesda criteria when considered individually also showed low sensitivity. We have, however, previously demonstrated that these criteria were neither sensitive nor specific in an unselected series of CRC cases. Our combined observations indicate that the prevalence of MSH6 mutations may be higher than currently assumed, and their penetrance and expression may differ from what is currently assumed. These findings are in keeping with the Mallorca guidelines, which recommend that MSI analysis and/or IHC should be performed on all CRCs. ${ }^{25}$ In addition, we suggest that such testing should be applied to all incident cancers in the Lynch syndrome tumour spectrum to increase the rate of detection of MMR mutation carriers.

Acknowledgements We thank the families that have actively contributed to this study, by giving us information and permission to study them. The assistance of the laboratory staff and clinicians in all Norwegian medical, genetic and pathological laboratories involved in testing for Lynch syndrome (HNPCC) is greatly appreciated.

\section{Competing interests None.}

Contributors Conception: WS, PM. Clinical data: EMG, PM, AS, LFE, IB, CJ, LM. Mutation analyses including MSI: WS, BIH, PAA, SA, LASL, BG. IHC: HA, IMB-L. Manuscript writing: WS, PM, EMG. Approval of final manuscript: all.

Provenance and peer review Not commissioned; externally peer reviewed.

\section{REFERENCES}

1. Vasen HF, Mecklin JP, Khan PM. Lynch HT. The International Collaborative Group on Hereditary Non-Polyposis Colorectal Cancer (ICG-HNPCC). Dis Colon Rectum 1991;34:424-5.

2. Wijnen JT, Vasen HF, Khan PM, Zwinderman AH, van der Klift H, Mulder A, Tops C, Møller P, Fodde R. Clinical findings with implications for genetic testing in families with clustering of colorectal cancer. N Engl J Med 1998;339:511-18.

3. Wijnen J, de Leeuw W, Vasen $H$, van der Klift H, Møller P, Stormorken A, MeijersHeijboer H, Lindhout D, Menko F, Vossen S, Möslein G, Tops C, Bröcker-Vriends A Wu Y, Hofstra R, Sijmons R, Cornelisse C, Morreau H, Fodde R. Familial endometrial cancer in female carriers of MSH6 germline mutations. Nat Genet 1999;23:142-4.

4. Vasen HF, Watson P, Mecklin JP, Lynch HT. New clinical criteria for hereditary nonpolyposis colorectal cancer (HNPCC, Lynch syndrome) proposed by the International Collaborative group on HNPCC. Gastroenterology 1999:116:1453-6.

5. Rodriguez-Bigas MA, Boland CR, Hamilton SR, Henson DE, Jass JR, Khan PM, Lynch H, Perucho M, Smyrk T, Sobin L, Srivastava S. A national cancer institute workshop on hereditary nonpolyposis colorectal cancer syndrome: meeting highlights and Bethesda guidelines. J Natl Cancer Inst 1997;89:1758-62.

6. Umar A, Boland CR, Terdiman JP, Syngal S, de la Chapelle A, Rüschoff J, Fishel R, Lindor NM, Burgart LJ, Hamelin R, Hamilton SR, Hiatt RA, Jass J, Lindblom A, Lynch HT, Peltomaki P, Ramsey SD, Rodriguez-Bigas MA, Vasen HF, Hawk ET, Barrett JC, Freedman AN, Srivastava S. Revised Bethesda guidelines for hereditary nonpolyposis colorectal cancer (Lynch syndrome) and microsatellite instability. J Natl Cancer Inst 2004;96:261-8.

7. Grindedal EM, Moller P, Eeles R, Stormorken AT, Bowitz-Lothe IM, Landrø SM, Clark N, Kvåle R, Shanley S, Maehle L. Germ-line mutations in mismatch repair genes associated with prostate cancer. Cancer Epidemiol Biomarkers Prev 2009; 18:2460-7.

8. Lynch HT, Lynch JF. Lynch syndrome: history and current status. Dis Markers 2004;20:181-98.

9. Vasen HF, Möslein G, Alonso A, Bernstein I, Bertario L, Blanco I, Burn J, Capella G, Engel C, Frayling I, Friedl W, Hes FJ, Hodgson S, Mecklin JP, Møller P, Nagengast F, 
Parc Y, Renkonen-Sinisalo L, Sampson JR, Stormorken A, Wijnen J. Guidelines for the clinical management of Lynch syndrome (hereditary non-polyposis cancer). J Med Genet 2007:44:353-62.

10. Vasen HF, Hendriks $Y$, de Jong AE, van Puijenbroek M, Tops $C$, Bröcker-Vriends AH, Wijnen JT, Morreau H. Identification of HNPCC by molecular analysis of colorectal and endometrial tumors. Dis Markers 2004:20:207-13.

11. Stormorken AT, Bowitz-Lothe IM, Noren T, Kure E, Aase S, Wijnen J, Apold J, Heimdal K, Møller P. Immunohistochemistry identifies carriers of mismatch repair gene defects causing hereditary nonpolyposis colorectal cancer. J Clin Oncol 2005;23:4705-12

12. Trano G, Sjursen W, Wasmuth HH, Hofsli E, Vatten LJ. Performance of clinical guidelines compared with molecular tumour screening methods in identifying possible Lynch syndrome among colorectal cancer patients: a Norwegian populationbased study. Br J Cancer. Published Online First: 7 January 2010 (doi:10.1038/sj. bjc.6605509).

13. Nystrom-Lahti M, Kristo P, Nicolaides NC, Chang SY, Aaltonen LA, Moisio AL, Järvinen HJ, Mecklin JP, Kinzler KW, Vogelstein B. Founding mutations and Alumediated recombination in hereditary colon cancer. Nat Med 1995;1:1203-6.

14. Foulkes WD, Thiffault I, Gruber SB, Horwitz M, Hamel N, Lee C, Shia J, Markowitz A, Figer A, Friedman E, Farber D, Greenwood CM, Bonner JD, Nafa K, Walsh T, Marcus V, Tomsho L, Gebert J, Macrae FA, Gaff CL, Paillerets BB, Gregersen PK, Weitzel JN, Gordon PH, MacNamara E, King MC, Hampel H, De La Chapelle A, Boyd J, Offit K, Rennert G, Chong G, Ellis NA. The founder mutation $\mathrm{MSH}^{*} 1906 \mathrm{G}->\mathrm{C}$ is an important cause of hereditary nonpolyposis colorectal cancer in the Ashkenazi Jewish population. Am J Hum Genet 2002;71:1395-412.

15. Wagner A, Barrows A, Wijnen JT, van der Klift $H$, Franken PF, Verkuijlen $P$, Nakagawa H, Geugien M, Jaghmohan-Changur S, Breukel C, Meijers-Heijboer H, Morreau $H$, van Puijenbroek $M$, Burn J, Coronel S, Kinarski $Y$, Okimoto $R$, Watson $P$, Lynch JF, de la Chapelle A, Lynch HT, Fodde R. Molecular analysis of hereditary nonpolyposis colorectal cancer in the United States: high mutation detection rate among clinically selected families and characterization of an American founder genomic deletion of the MSH2 gene. Am J Hum Genet 2003;72:1088-100.

16. Clendenning M, Baze ME, Sun S, Walsh K, Liyanarachchi S, Fix D, Schunemann V, Comeras I, Deacon M, Lynch JF, Gong G, Thomas BC, Thibodeau SN, Lynch HT, Hampel $\mathrm{H}$, de la Chapelle A. Origins and prevalence of the American founder mutation of MSH2. Cancer Res 2008:68:2145-53.

17. Woods MO, Williams P, Careen A, Edwards L, Bartlett S, McLaughlin JR, Younghusband $\mathrm{HB}$. A new variant database for mismatch repair genes associated with Lynch syndrome. Hum Mutat 2007:28:669-73.

18. Stormorken AT, Müller W, Lindblom A, Heimdal $K$, Aase $S$, Lothe IM, Norèn $T$, Wijnen JT, Möslein G, Møller P. The inframe MSH2 codon 596 deletion is linked with HNPCC and associated with lack of MSH2 protein in tumours. Fam Cancer 2003:2:9-13.

19. Wijnen J, Khan PM, Vasen $H$, van der Klift $H$, Mulder $A$, van Leeuwen-Cornelisse I, Bakker B, Losekoot M, Møller P, Fodde R. Hereditary nonpolyposis colorectal cancer families not complying with the Amsterdam criteria show extremely low frequency of mismatch-repair-gene mutations. Am J Hum Genet 1997:61:329-35.

20. Nilbert M, Wikman FP, Hansen TV, Krarup HB, Orntoft TF, Nielsen FC, Sunde L, Gerdes AM, Cruger D, Timshel S, Bisgaard ML, Bernstein I, Okkels H. Major contribution from recurrent alterations and MSH6 mutations in the Danish Lynch syndrome population. Fam Cancer 2009;8:75-83.
21. Kurzawski G, Suchy J, Lener M, Kłujszo-Grabowska E, Kładny J, Safranow K, Jakubowska K, Jakubowska A, Huzarski T, Byrski T, Debniak T, Cybulski C, Gronwald J, Oszurek 0, Oszutowska D, Kowalska E, Góźdź S, Niepsuj S, Słomski R, Pławski A, Łacka-Wojciechowska A, Rozmiarek A, Fiszer-Maliszewska Ł, Bebenek M Sorokin D, Sasiadek MM, Stembalska A, Grzebieniak Z, Kilar E, Stawicka M, Godlewski D, Richter P, Brozek I, Wysocka B, Limon J, Jawień A, Banaszkiewicz Z Janiszewska H, Kowalczyk J, Czudowska D, Scott RJ, Lubiński J. Germline MSH2 and MLH1 mutational spectrum including large rearrangements in HNPCC families from Poland (update study). Clin Genet 2006;69:40-7.

22. Sjursen W, Bjornevoll I, Engebretsen LF, Fjelland K, Halvorsen T, Myrvold HE. A homozygote splice site PMS2 mutation as cause of Turcot syndrome gives rise to two different abnormal transcripts. Fam Cancer 2009:8:179-86.

23. Takahashi M, Shimodaira H, Andreutti-Zaugg C, Iggo R, Kolodner RD, Ishioka C. Functional analysis of human MLH1 variants using yeast and in vitro mismatch repai assays. Cancer Res 2007:67:4595-604.

24. Trano G, Wasmuth HH, Sjursen W, Hofsli E, Vatten LJ. Awareness of heredity in colorectal cancer patients is insufficient among clinicians: a Norwegian populationbased study. Colorectal Dis 2009;11:456-61.

25. Vasen HF, Möslein G, Alonso A, Aretz S, Bernstein I, Bertario L, Blanco I, Bulow S, Burn J, Capella G, Colas C, Engel C, Frayling I, Rahner N, Hes FJ, Hodgson S, Mecklin JP, Møller P, Myrhøj T, Nagengast FM, Parc Y, Ponz de Leon M, Renkonen-Sinisalo L, Sampson JR, Stormorken A, Tejpar S, Thomas HJ, Wijnen J, Lubinski J, Järvinen H Claes E, Heinimann K, Karagiannis JA, Lindblom A, Dove-Edwin I, Müller H. Recommendations to improve identification of hereditary and familial colorectal cancer in Europe. Fam Cancer 2010;9:109-15

26. Baglietto L, Lindor NM, Dowty JG, White DM, Wagner A, Gomez Garcia EB, Vriends AH. Dutch Lynch Syndrome Study Group,Cartwright NR, Barnetson RA Farrington SM, Tenesa A, Hampel $H$, Buchanan D, Arnold S, Young J, Walsh MD, Jass J, Macrae F, Antill Y, Winship IM, Giles GG, Goldblatt J, Parry S, Suthers G, Leggett B, Butz M, Aronson M, Poynter JN, Baron JA, Le Marchand L, Haile R, Gallinger S, Hopper JL, Potter J, de la Chapelle A, Vasen HF, Dunlop MG, Thibodeau SN, Jenkins MA. Risks of Lynch syndrome cancers for MSH6 mutation carriers. J Natl Cancer Inst Published Online First: 22 December 2009 (doi:10.1093/jnci/djp473).

27. Plaschke J, Engel C, Kruger S, Holinski-Feder E, Pagenstecher C, Mangold E, Moeslein G, Schulmann K, Gebert J, von Knebel Doeberitz M, Rüschoff J, Loeffler M, Schackert HK. Lower incidence of colorectal cancer and later age of disease onset in 27 families with pathogenic MSH6 germline mutations compared with families with MLH1 or MSH2 mutations: the German hereditary nonpolyposis colorectal cancer consortium. J Clin Oncol 2004:22:4486-94.

28. Horii A, Han HJ, Sasaki S, Shimada M, Nakamura Y. Cloning, characterization and chromosomal assignment of the human genes homologous to yeast PMS1, a membe of mismatch repair genes. Biochem Biophys Res Commun 1994;204:1257-64.

29. Nicolaides NC, Carter KC, Shell BK, Papadopoulos N, Vogelstein B, Kinzler KW. Genomic organization of the human PMS2 gene family. Genomics 1995;30:195-206

30. De Vos M, Hayward BE, Picton S, Sheridan E, Bonthron DT. Novel PMS2 pseudogenes can conceal recessive mutations causing a distinctive childhood cance syndrome. Am J Hum Genet 2004;74:954-64.

31. Taylor CF, Charlton RS, Burn J, Sheridan E, Taylor GR. Genomic deletions in MSH2 or MLH1 are a frequent cause of hereditary non-polyposis colorectal cancer identification of novel and recurrent deletions by MLPA. Hum Mutat 2003:22:428-33. 